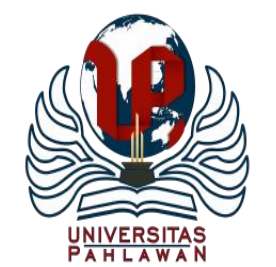

Jurnal Basicedu Volume 2 Nomor 1 April 2020 Halaman 15-22

EDUKATIF: JURNAL ILMU PENDIDIKAN

Research \& Learning inEducation

https://edukatif.org/index.php/edukatif/index

\title{
Optimisme Dengan Problem Focused Coping Pada Mahasiswa Yang Sedang Mengerjakan Tugas Akhir
}

\author{
Gabriella Khriste Dea Valentsia ${ }^{1}$, Sutarto Wijono ${ }^{2}$ \\ Universitas Kristen Satya Wacana, Jawa Tengah, Indonesia ${ }^{1,2}$ \\ e-mail : gabriellakdv@gmail.com ${ }^{1}$, wijonosutarto@gmail.com ${ }^{2}$
}

\begin{abstract}
Abstrak
Penelitian ini bertujuan untuk mengetahui ada tidaknya hubungan antara optimisme dan problem focused coping. Penelitian ini dilakukan pada tahun 2016 oleh mahasiswa Fakultas Psikologi Universitas Kristen Satya Wacana yang melakukan tugas akhir mereka dengan total 134 siswa menggunakan teknik sampling insidental. Metode pengumpulan data yang digunakan dalam penelitian ini menggunakan skala optimisme menggunakan skala adaptasi oleh Adilia (2010) yang disusun mengacu pada aspek optimisme dari teori Seligman (2001) yaitu aspek permanen, pervasiveness, dan aspek personalisasi untuk mengukur tingkat optimisme pada siswa yang saat ini melakukan tugas akhir dan skala masalah yang berfokus pada coping menggunakan WCQ (Ways of Coping Questionnaire) yang dimiliki oleh Folkman dan Lazarus, 1988 untuk mengukur bagaimana siswa menangani atau mengatasi masalah yang menjadi sumber stres ketika menyelesaikan proyek akhir dengan mencari berbagai informasi. Analis data menggunakan uji korelasi Product Moment dan Pearson, dengan hasil $\mathrm{r}=0,647 ; \mathrm{p}<0,05$, sehingga dapat disimpulkan bahwa ada hubungan positif yang signifikan antara optimisme dan problem focused coping pada siswa yang mengerjakan tugas akhir.
\end{abstract}

Kata Kunci: Optimisme, problem focused coping

\begin{abstract}
This study aims to determine is there a relationship or not between optimism and problem focused coping. This research conducted on 2016 by Satya Wacana Christian University Faculty of Psychology students who did their final project with total 134 students using incidental sampling technique. Data collection methods used in this study use an optimism scale using an adaptation scale by Adilia (2010) which prepared referring to aspects of optimism from Seligman's theory (2001) namely the aspects of permanence, pervasiveness, and personalization aspects to measure the level of optimism in students who are currently do the final project and scale the problem focused coping using WCQ (Ways of Coping Questionnaire) owned by Folkman and Lazarus, 1988 to measure how students deal with or overcome problems that are sources of stress when completing the final project by finding various information. Data analysts used Product Moment and Pearson correlation tests, with results $r=0.647 ; p<0.05$, so it can be concluded that there is a significant positive relationship between optimism and problem focused coping on students who are working on the final project..
\end{abstract}

Keywords: optimism, problem focused coping

@Edukasi: Jurnal Ilmu Pendidikan 2020

$\triangle$ Corresponding author :

Address :

ISSN 2656-8063 (Media Cetak)

Email

ISSN 2656-8071 (Media Online)

Phone 
16 Optimisme dengan Problem Focused Coping pada mahasiswa yang sedang mengerjakan tugas akhir - Gabriella Khriste Dea Valentsia, Sutarto Wijono

\section{PENDAHULUAN}

Sebagian besar mahasiswa

memiliki keinginan untuk menyelesaikan tugas akhir kuliahnya dengan menggunakan banyak cara, diantaranya dengan menggali informasi sebanyak mungkin mulai dari pergi ke perpustakaan, warung internet dan membeli berbagai macam buku dan lain sebagainya. Namun tetap saja ada kendala yang dirasakan oleh setiap mahasiswa dalam menyelesaikan tugas akhir. Hal ini justru menjadi beban tersendiri, dimana tidak sedikit dari mahasiswa yang seringkali merasa kesulitan dalam mencari informasi yang diperlukan untuk kebutuhan tugas akhirnya hingga pada akhirnya mereka mengalami perasaan gelisah, tidak nyaman, bahkan tertekan sampai akhirnya mereka mengalami stress. Menurut Brecht (dalam Azmi, 2016) stress adalah gangguan pada tubuh dan pikiran yang disebabkan oleh perubahan dan tuntutan kehidupan, yang dipengaruhi baik oleh lingkungan maupun penampilan individu didalam lingkungan tersebut. Dalam menyelesaikan stress tersebut, setiap mahasiswa memiliki strategi penyelesaian yang berbeda-beda untuk mengatasi stres yang dialami dalam menyelesaikannya, yaitu melalui strategi emotion focused coping dan problem focused coping.

Pernyataan tersebut dapat dibuktikan dari hasil observasi dan wawancara dengan 5 mahasiswa yang telah penulis lakukan pada hari Kamis, 16 Mei 2019. Dari hasil observasi dan wawancara penulis menemukan adanya fenomena sebagai berikut: dari 5 mahasiswa ada 3 yang seringkali merasa tertekan dalam mempersiapkan tugas akhirnya yang akhirnya mereka mencari dukungan berupa informasi atau dukungan sosial, sementara beberapa diantaranya sering kali merasa bahwa dukungan sosial bukanlah jalan keluar untuk permasalahan yang mereka hadapi dan mereka cenderung mengerjakan tugas akhir sesuai dengan mood mereka saja tanpa memerlukan dukungan dari siapapun. Pernyataan tersebut di dukung oleh Lazarus dan Folkman (1989) mengatakan bahwa metode coping dibagi menjadi dua model, yaitu coping yang berfokus pada permasalahan (problem focused coping) yang ditujukan pada penyelesaian masalah atau melakukan sesuatu untuk mengubah sumber tekanan dan coping yang berfokus pada emosi (emotion focused coping), ditujukan untuk mengurangi atau mengelola tekanan emosional yang terkait dengan situasi. Tetapi penulis mendapati bahwa cara yang sering kali dilakukan oleh mahasiswa dalam menyelesaikan masalah mereka adalah problem focused coping.

Problem focused coping memberikan dampak positif bagi mahasiswa, dimana mahasiswa mampu untuk menghilangkan masalah yang menjadi pemicu stress. Hal ini di dukung oleh penelitian yang telah di lakukan oleh Herman dan Tetrick, 2009 (dalam I Gde, 2018) yang mengatakan bahwa problem focused coping dapat ditujukan untuk mengurangi efek dari stressor yang disebabkan oleh reaksi emosional. Dari hasil temuan tersebut menunjukkan bahwa dampak tersebut dapat membantu mahasiswa dalam untuk menyekesaikan sumber masalah, melakukan eksplorasi, berfokus pada sumber masalah, memberikan bentuk pertolongan yang nyata, melakukan perencanaan untuk menyelesaikan masalah, membangun relasi, bahkan mengatur dan mengubah situasi.

Oleh karena itu penelitian tentang optimisme dan problem focused coping ini penting untuk dilakukan. Hasil riset yang menyatakan hal tersebut ditemukan Sarafino (1998) yang mengatakan bahwa problem focused coping merupakan salah satu usaha yang berfungsi untuk mengurangi tuntutan dari situasi yang penuh stress atau mengembangkan kemampuan untuk 
17 Optimisme dengan Problem Focused Coping pada mahasiswa yang sedang mengerjakan tugas akhir - Gabriella Khriste Dea Valentsia, Sutarto Wijono

menghadapi stress. Kemudian Lazarus dan Folkman (1989) juga mendukung hasil temuan diatas yang mengatakan bahwa problem focused coping ditujukan untuk menyelesaikan masalah atau melakukan sesuatu untuk mengubah sumber stres.

Penulis menganggap bahwa sebagian besar mahasiswa di Fakultas Psikologi cenderung berfikir positif dalam kehidupannya, yakin dengan keputusan yang diambil, bahkan memiliki kepercayaan diri. Seorang mahasiswa yang memiliki kepercayaan diri yang besar, bisa dikatakan juga bahwa mahasiswa tersebut mempunyai optimisme yang tinggi. Salah satu masalah yang sering dihadapi oleh mahasiswa pada akhir periode studi adalah ketika mereka diperhadapkan dengan penyusunan tugas akhir dan hal tersebut sering kali membuat mahasiswa mengeluh dan merasa pesimis dengan proses tersebut. Namun, untuk mahasiswa yang optimis tidak mudah untuk menyerah dalam menghadapi kegagalan-kegagalan yang mengarah pada stress, melainkan tetap berusaha mencari solusi untuk masalah tugas akhir yang dihadapi. Seligman (Lestari, 2002), menyatakan bahwa optimisme merupakan keyakinan individu dalam menanggapi bahwa peristiwa buruk atau kegagalan hanya bersifat sementara, tidak mempengaruhi semua aktivitas dan tidak mutlak disebabkan diri sendiri tetapi bisa situasi, nasib atau orang lain. Sementara Scheier dan Carver (1985) mendefinisikan optimisme sebagai harapan umum untuk hasil positif daripada negatif." Reina (Raditya, 2009), mengatakan bahwa orang yang optimis lebih mampu mengatasi stress daripada orang yang pesimis. Dengan demikian, jika seorang mahasiswa yang memiliki sikap optimis yang rendah maka problem focused coping pun akan rendah. Dengan kata lain jika seseorang mahasiswa mempunyai kemauan agar tugas akhirnya cepat selesai, maka mereka bersikap optimis untuk meningkatkan problem focused coping mereka.

Berdasarkan uraian diatas, maka peneliti tertarik untuk meneliti tentang hubungan antara optimisme dan problem focused coping pada mahasiswa yang sedang mengerjakan tugas akhir.

\section{METODE PENELITIAN}

Jenis penelitian yang digunakan adalah penelitian kuantitatif dengan metode korelasional. Dimana variabel bebas pada penelitian ini adalah optimisme dan variabel terikatnya adalah problem focused coping.

Populasi dalam penelitian ini adalah mahasiswa Fakultas Psikologi angkatan 2016 yang sedang mengerjakan tugas akhir dengan jumlah populasi 202 orang. Teknik yang digunakan dalam perhitungan sampel penelitian didasarkan pada teknik non probability sampling, yaitu dimana tidak semua unit populasi memiliki kesempatan yang sama untuk menjadi anggota sampel dan dangan menggunakan teknik incidental sampling yaitu penentuan sampel berdasarkan kebetulan, dimana siapa saja yang secara kebetulan bertemu dengan peneliti dapat digunakan sebagai sampel, bila dipandang orang yang kebetulan ditemui itu cocok sebagai sumber data. Atas dasar teknik incidental sampling, penulis juga menggunakan rumus Slovin dalam mengambil sampel sehingga didapatkan sebanyak 134 mahasiswa.

Dalam mengumpulkan data penelitian, peneliti menggunakan 2 variabel psikologis yaitu optimisme dan problem focused coping. Variabel optimisme dalam penelitian ini diukur dengan skala adaptasi oleh Adilia (2010) yang disusun mengacu pada aspek-aspek optimisme dari teori Seligman (2001) yakni aspek permanence, pervasiveness, dan aspek personalization. Dan untuk mengukur variabel problem focused coping 
18 Optimisme dengan Problem Focused Coping pada mahasiswa yang sedang mengerjakan tugas akhir - Gabriella Khriste Dea Valentsia, Sutarto Wijono

dengan menggunakan WCQ (Ways of Coping Questionnaire) milik Folkman \& Lazarus, 1988. Variabel problem focused coping dalam penelitian ini diukur dengan menggunakan skala Likert yang megacu pada aspek-aspek Folkman dan Lazarus (1988) yang meliputi seeking social support, confrontive coping, planful problem solving.

Variabel problem focused coping dalam penelitian ini berumlah 30 aitem yang masingmasing terdapat 15 aitem favorable dan 15 aitem unfavorable. diukur dengan menggunakan skala Likert dimodifikasi menjadi empat pilihan respon, yaitu sangat sesuai (SS), sesuai (S), tidak sesuai (TS), dan sangat tidak sesuai (STS). Berdasarkan uji reliabilitas, nilai yang di dapat adalah 0,813 dengan menggunakan deskriminasi aitem 0,3. Variabel optimisme dalam penelitian ini berjumlah 30 aitem yang masing-masing terdapat 15 aitem favorable dan 15 aitem unfavorable. Skala Likert dimodifikasi menjadi empat pilihan respon, yaitu sangat sesuai (SS), sesuai (S), tidak sesuai (TS), dan sangat tidak sesuai (STS). Berdasarkan uji reliabilitas, nilai yang di dapat adalah 0,905 dengan deskriminasi aitem 0,3 .

\section{HASIL DAN PEMBAHASAN PENELITIAN}

Hasil Pembahasan dapat dijabarkan sebagai berikut:

\section{Tabel 1 Kategorisasi Variabel} Optimisme

\begin{tabular}{|c|c|c|c|c|c|}
\hline No & Interval & Kategori & Frekuensi & Persentase & Mean \\
\hline 1. & $\begin{array}{l}28 \leq X \\
<44,8\end{array}$ & $\begin{array}{l}\text { Sangat } \\
\text { Rendah }\end{array}$ & 39 & $29,1 \%$ & \multirow{6}{*}{52,46} \\
\hline 2. & $\begin{array}{l}44,8 \geq \\
X< \\
61,6\end{array}$ & Rendah & 83 & $61,9 \%$ & \\
\hline 3. & $\begin{array}{l}61,6 \geq \\
X< \\
78,4\end{array}$ & Sedang & 12 & $9 \%$ & \\
\hline 4. & $\begin{array}{l}78,4 \geq \\
X< \\
95,2\end{array}$ & Tinggi & 0 & $0 \%$ & \\
\hline \multirow[t]{2}{*}{5.} & $\begin{array}{l}95,2 \geq \\
X \leq \\
112\end{array}$ & $\begin{array}{l}\text { Sangat } \\
\text { Tinggi }\end{array}$ & 0 & $0 \%$ & \\
\hline & & Jumlah & 134 & $100 \%$ & \\
\hline
\end{tabular}

Pada tabel 1 kategorisasi skor variabel optimisme dari sebanyak 134 subjek menunjukan tingkat penyebaran kategori dari sangat rendah hingga sangat tinggi, dapat dilihat bahwa pada kategori "Sangat Rendah" didapati persentase sebesar 29,1\%, pada kategori "Rendah" didapati persentase 61,9\%, pada kategori "Sedang" didapati persentase 9\%, kemudian pada kategori "Tinggi" didapati persentase $0 \%$, dan pada kategori "Sangat Tinggi" juga didapati persentase $0 \%$. Berdasarkan tabel diatas juga dapat dilihat bahwa mean atau rata-rata sebesar 52,46 yang ada pada kategori "Rendah". Berdasarkan seleksi aitem dari uji reliabilitas terdapat 28 aitem yang dinyatakan lolos atau baik dan 2 aitem yang gugur dari jumlah keseluruhan sebanyak 30 aitem dengan koefisien cronbach's alpha sebesar 0,905. Berdasarkan data di atas didapat bahwa tingkat optimisme pada sebanyak 134 mahasiswa yang sedang mengerjakan tugas akhir berada pada tingkat rendah.

Tabel 2 Kategori Variabel Problem Focused Coping

\begin{tabular}{|c|c|c|c|c|c|}
\hline No & Interval & Kategori & Frekuensi & Persentase & Mean \\
\hline 1. & $\begin{array}{l}14 \leq X \\
<22,4\end{array}$ & $\begin{array}{l}\text { Sangat } \\
\text { Rendah }\end{array}$ & 12 & $8,9 \%$ & \multirow{5}{*}{27,05} \\
\hline 2. & $\begin{array}{l}22,4 \geq \\
X< \\
30,8\end{array}$ & Rendah & 77 & $57,5 \%$ & \\
\hline 3. & $\begin{array}{l}30,8 \geq \\
X< \\
39,2\end{array}$ & Sedang & 44 & $32,84 \%$ & \\
\hline 4. & $\begin{array}{l}39,2 \geq \\
X< \\
47,6\end{array}$ & Tinggi & 1 & $0,74 \%$ & \\
\hline \multirow[t]{2}{*}{5.} & $\begin{array}{l}47,6 \geq \\
X \leq 56\end{array}$ & $\begin{array}{l}\text { Sangat } \\
\text { Tinggi }\end{array}$ & 0 & $0 \%$ & \\
\hline & & Jumlah & 134 & $100 \%$ & \\
\hline
\end{tabular}

Pada tabel 2. kategorisasi skor variabel problem focused coping dari sebanyak 134 subjek menunjukan tingkat penyebaran kategori dari sangat rendah hingga sangat 
19 Optimisme dengan Problem Focused Coping pada mahasiswa yang sedang mengerjakan tugas akhir - Gabriella Khriste Dea Valentsia, Sutarto Wijono

tinggi, dapat dilihat bahwa pada kategori "Sangat Rendah" didapati persentase sebesar $8,9 \%$, pada kategori "Rendah" didapati persentase $57,5 \%$, pada kategori "Sedang" didapati persentase $32,84 \%$, kemudian pada kategori "Tinggi" didapati persentase $0,74 \%$, dan pada kategori "Sangat Tinggi" didapati persentase $0 \%$. Berdasarkan tabel diatas juga dapat dilihat bahwa mean atau rata sebesar 27,05 yang ada pada kategori "Rendah".

Berdasarkan seleksi aitem dari uji reliabilitas terdapat 14 aitem yang dinyatakan lolos atau baik dan 16 aitem yang gugur dari jumlah keseluruhan sebanyak 30 aitem dengan koefisien cronbach's alpha sebesar 0,813. Berdasarkan data di atas didapat bahwa tingkat problem focused coping pada sebanyak 134 mahasiswa yang sedang mengerjakan tugas akhir berada pada tingkat rendah.

Tabel 3. Normalitas skala Optimisme dan Problem Focused Coping One-Sample Kolmogorov-Smirnov Test

\begin{tabular}{|c|c|c|c|}
\hline & & $\begin{array}{l}\text { OPTI } \\
\text { MIS }\end{array}$ & PFC \\
\hline \multicolumn{2}{|l|}{$\mathrm{N}$} & 134 & 134 \\
\hline \multirow{2}{*}{$\begin{array}{l}\text { Normal } \\
\text { Parameters }\end{array}$} & Mean & 49.84 & 28.55 \\
\hline & $\begin{array}{l}\text { Std. } \\
\text { Deviation }\end{array}$ & 8.956 & 4.733 \\
\hline \multirow{3}{*}{$\begin{array}{l}\text { Most Extreme } \\
\text { Differences }\end{array}$} & Absolute & .067 & .090 \\
\hline & Positive & .053 & .044 \\
\hline & Negative & -.067 & -.090 \\
\hline \multicolumn{2}{|c|}{ Kolmogorov-Smirnov Z } & .776 & 1.041 \\
\hline \multicolumn{2}{|c|}{ Asymp. Sig. (2-tailed) } & .583 & .229 \\
\hline
\end{tabular}

a. Test distribution is Normal.

b. Calculated from data.

Uji normalitas menggunakan uji Kolmogrov-Smirnov yang menunjukkan variabel optimisme memiliki nilai K-S-Z sebesar 0.776 dengan signifikansi 0.583 ( $>0.05)$. Pada variabel problem focused coping memiliki nilai K-S-Z sebesar 1.041 dengan signifikansi sebesar 0.229 ( $\mathrm{p}>0.05)$. Dengan demikian dapat disimpulkan bahwa variabel optimisme berdistribusi normal dengan problem focused coping berdistribusi normal

Berdasarkan uji linearitas menggunakan Anova, diperoleh nilai deviation from linearity sebesar 0.862 dengan sig.= 0.682 ( $\mathrm{p}>0.05)$ yang menunjukkan ada hubungan linear antara variabel optimisme dengan problem focused coping.

Tabel. 4 uji linearitas

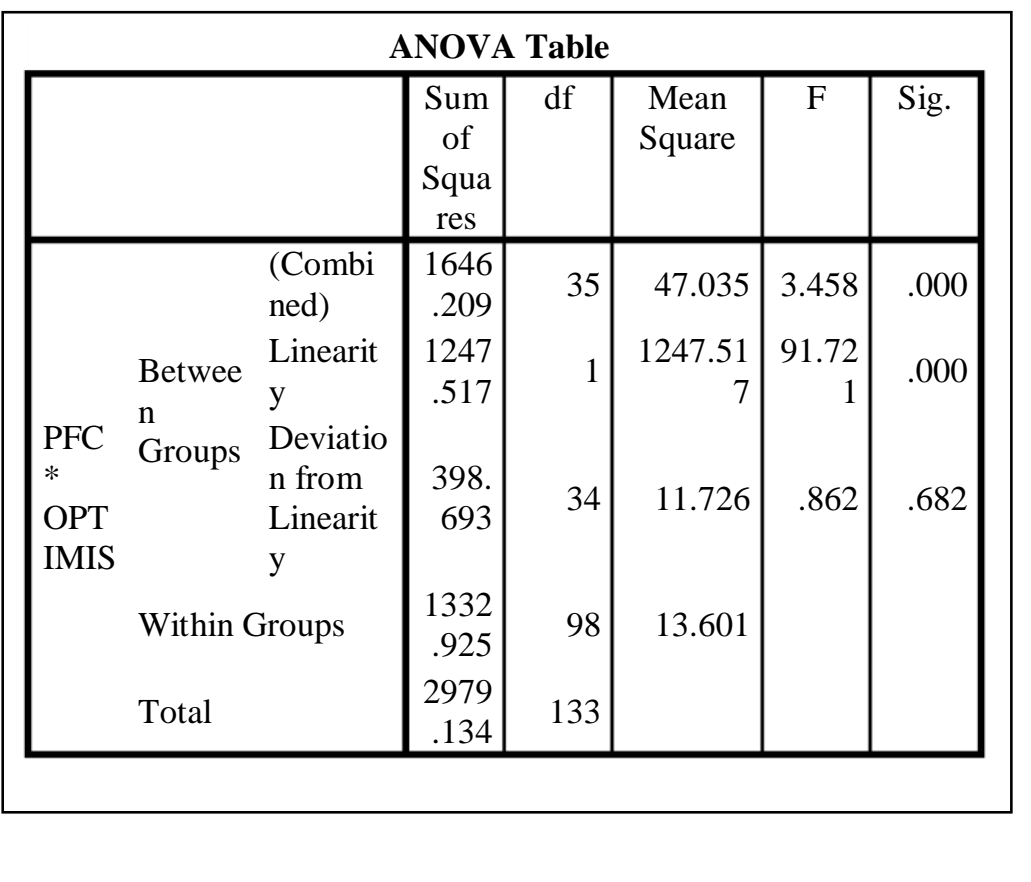

Berdasarkan uji asumsi yang telah dilakukan, diketahui terdapat data yang berdistribusi normal dan variabel penelitian linear. Sehingga uji korelasi dilakukan dengan menggunakan statiskit non-parametrik. Uji korelasi yang digunakan dalam penelitian ini adalah korelasi Product Moment \& Pearson. 
20 Optimisme dengan Problem Focused Coping pada mahasiswa yang sedang mengerjakan tugas akhir - Gabriella Khriste Dea Valentsia, Sutarto Wijono

\section{Tabel 5. Korelasi antara Optimisme dan Problem Focused Coping}

\section{Correlations}

\begin{tabular}{llrr}
\hline & & OPTIMIS & \multicolumn{2}{l}{ PFC } \\
\hline \multirow{2}{*}{ OPTIMIS } & \multicolumn{1}{l}{ Pearson Correlation } & 1 & $.647^{* *}$ \\
\cline { 2 - 4 } & Sig. (1-tailed) & & .000 \\
\cline { 2 - 4 } & $\mathrm{N}$ & 134 & 134 \\
\hline \multirow{3}{*}{ PFC } & Pearson Correlation & $.647^{* *}$ & 1 \\
\cline { 2 - 4 } & Sig. (1-tailed) & .000 & \\
\cline { 2 - 4 } & $\mathrm{N}$ & 134 & 134
\end{tabular}

**. Correlation is significant at the 0.01 level (1-tailed).

Dengan menggunakan uji korelasi Product Moment \& Pearson diperoleh koefisien korelasi antara optimisme dengan problem focused coping sebesar $\mathrm{r}=0.647$ dengan sig. $0.000(\mathrm{p}<0.05)$. Yang berarti ada hubungan positif antara variabel optimisme dengan problem focused coping pada mahasiswa yang sedang mengerjakan tugas akhir.

Dalam penelitian ini penulis merumuskan hipotesis penelitian sebagai berikut terdapat hubungan positif dan signifikan antara optimisme dengan problem focused coping. Hasil penelitian yang diolah melalui uji korelasi product moment \& pearson menunjukkan koefisien korelasi $(\mathrm{r})=$ $0.647 ; \mathrm{p}<0.05$ yang berarti ada hubungan positif dan signifikan antara optimisme dengan problem focused coping pada mahasiswa yang sedang mengerjakan tugas akhir. Hal ini berarti semakin tinggi optimisme maka problem focused coping akan semakin meningkat, begitu pula sebaliknya. Dengan kata lain, variabel optimisme memiliki peran terhadap munculnya variabel problem focused coping. Hasil penelitian tersebut didukung pula oleh analisis deskriptif pada tabel 1.1 dan tabel 1.2 yang menunjukkan bahwa optimisme dan problem focused coping pada mahasiswa yang sedang mengerjakan tugas akhir berada pada kategori rendah. Ada beberapa alasan yang menyebabkan ada hubungan positif significan antara optimisme dengan problem focused coping. Pertama, sebagian besar mahasiswa mampu menyelesaikan masalah yang dihadapi dalam penyelesaian tugas akhir dengan baik, dimana dalam hal ini mahasiswa memiliki optimisme dalam menyelesaikan masalah yang menjadi pemicu stres dengan mencari berbagai informasi dengan menerapkan problem focused coping. Pernyataan ini didukung oleh penelitian yang dilakukan oleh Listiana (2009) menyatakan bahwa ada hubungan signifikan dan positif antara optimisme dan problem focused coping. Hal ini menyatakan bahwa semakin tinggi optimisme pada mahasiswa yang mengerjakan tugas akhir, maka semakin tinggi juga problem focused coping.

Kedua, sebagian besar mahasiswa memiliki sikap optimis yang membawa kearah kebaikan karena adanya keinginan pada diri mahasiswa untuk menjadi lebih produktif dalam mengerjakan tugas akhir sehingga mereka dapat menerapkan problem focused coping, untuk mencapai keberhasilan dalam penyelesaian tugas akhir. Dalam hal lain, Pernyataan ini didukung oleh penelitian yang telah dilakukan oleh Azmi (2016) mengatakan bahwa ada hubungan antara optimisme dan problem focused coping, hal tersebut dapat dilihat ketika mahasiswa menghadapi suatu 
21 Optimisme dengan Problem Focused Coping pada mahasiswa yang sedang mengerjakan tugas akhir - Gabriella Khriste Dea Valentsia, Sutarto Wijono

masalah tinggi, maka problem focused coping yang dimunculkan akan cenderung baik.

Selain itu, sumbangan efektif optimisme terhadap problem focused coping sebesar $41.9 \%$ sedangkan sisanya dipengarui oleh faktor lain, seperti tidak adanya bantuan atau dukungan dari orang terdekat menjadikan mahasiswa tidak dapat menyelesaikan tugas akhirnya sebesar 58.1\%.Hal ini disebabkan karena pada sebagian mahasiswa Fakultas Psikologi Universitas Kristen Satya Wacana yang sedang mengerjakan tugas akhir merasa bahwa adanya optimisme yang tinggi dapat mengurangi permasalahan yang dapat menghambat penyelesaian tugas akhir dalam hal ini problem focused coping. Sementara pada sebagian mahasiswa lainnya, tinggi atau rendahnya optimisme yang mereka miliki tidak berpengaruh pada problem focused coping.

Penulis juga mencoba untuk menganalisis kembali bahwa masing-masing aspek dari optimisme memiliki korelasi yang signifikan dan positif dengan problem focused coing. Dimana dalam aspek pertama dalam variabel optimisme yaitu permanence yang ditunjukkan dengan $\mathrm{r}=0.548 ; \mathrm{p}<0.05$. Yang artinya, semakin tinggi keyakinan mahasiswa bahwa masalah yang dihadapi hanya bersifat sementara maka semakin tinggi juga problem focused coping. Dengan kata lain bahwa permanence memberikan peran bagi mahasiswa untuk meningkatkan problem focused coping. Hal ini didukung oleh oleh penelitian Seligman (Lestari, 2002) yang menyatakan bahwa permanence merupakan keyakinan individu dalam menanggapi bahwa peristiwa buruk atau kegagalan hanya bersifat sementara, sehingga mahasiswa dapat menerapkan problem focused coping dengan baik. Kemudian yang kedua yaitu aspek pervasiveness yang menunjukkan adanya hubungan signifikan dan positif dengan $\mathrm{r}=$ 0.617; $\mathrm{p}<0,05$ yang artinya pervasiveness memberikan keyakinan pada mahasiswa bahwa kegagalan dapat diatasi melalui penerapan problem focused coping. Selanjutnya pada aspek yang ketiga yaitu personalization juga menunjukkan hubungan signifikan dan positif dengan $r=0.591$; $\mathrm{p}<0.05$ maka ketika sebagian mahasiswa menganggap bahwa mereka memiliki personalization, maka dia cenderung dapat menyelesaikan masalahnya dengan problem focused coping.

\section{SIMPULAN}

Berdasarkan hasil penelitian ini terdapat hubungan positif antara optimisme dengan problem focused coping, yang berarti semakin tinggi optimisme maka semakin tinggi juga problem focused coping problem focused coping yang dimiliki mahasiswa, sebaliknya semakin rendah optimisme maka semakin rendah juga problem focused coping yang dimiliki mahasiswa.

\section{DAFTAR PUSTAKA}

Achroza, F. H. (2013). Hubungan antara komunikasi interpersonal dosen pembimbing mahasiswa dan problem focused coping dengan stress dalam menyusun skripsi pada mahasiswa FKIP bimbingan dan konseling Universitas 
Muria Kudus. Skripsi, Kudus: Fakultas Psikologi Universitas Muara Kudus.

Adilia, M. D. (2010). Hubungan self esteem dengan optimisme meriah kesuksesan karier pada mahasiswa fakultas psikologi UIN Syarif Hidayatullah Jakarta. Skripsi, Universitas Islam Negeri, Jakarta.

Arikunto, Suharsimi. (2005). Manajemen Penelitian. Jakarta: Rineka Cipta.

Atmawijaya, I. G. A. R. (2018). Pengaruh Strategi Coping Terhadap Stress Pada Perempuan Bali Yang Menjalani Triple Roles Di Instansi Militer Denpasar. Skripsi, Yogyakarta: Fakultas Psikologi Universitas Sanata Yogyakarta.

Azmi, S. F. (2016). Hubungan Antara Optimisme Dengan Kemampuan Problem Focused Coping Pada Mahasiswa Yang Bekerja Part Time. Skripsi, Malang: Fakultas Psikologi Universitas Muhammadiyah Malang.

Barlow, P. J. (2003). The measurement of optimism and hope in relation to college student retention and academic success. Dissertation Abstracts International: Section B: The Sciences and Engineering, 63(8-B), 3969.

Kadili, N. D. (2018). Kecerdasan Emosional dan Problem Focused Coping Pada Mahasiswa Yang Sedang Menyusun Skripsi. Skripsi, Universitas Sanata Dharma, Yogyakarta.

Kholifah, N., Indawati. (2017). Hubungan antara optimisme dengan problem focused coping, 4(1), 19-25.

Lazarus, R. S., \& Folkman, S. (1984). Stress, appraisal, and coping. New York: Springer

Listiana, W. (2008). Hubungan antara optimisme dan problem focused coping pada mahasiswa (Skripsi, Universitas Sanata Dharma, Yogyakarta).

Ningrum, D. A. (2011). Hubungan antara optimisme dan coping stres pada mahasiswa UEU yang sedang menyusun skripsi. Jurnal Psikologi, 9(1), 7.
Nurdin, A.A., Ahmad, \& Zainudin, K., (2016). Psychological Well-Being Ditinjau Dari Coping Strategy Mahasiswa Salah Jurusan, 1-11.

Saidah, N. A., (2016). Hubungan Optimisme Dengan Produktivitas Kerja Pada Karyawan Tata Usaha. Skripsi, Universitas Muhammadiyah, Malang.

Saleh Baqutayan, S. M. (2015). Stress and coping mechanisms: A historical overview. Mediterranean Journal of Social Sciences, 6(2S1), 479-488.

Sarafino. 1998. Health PSYCHOLOGY Biopsychology Interaction. Third Edition. John Willey and Sans. New York.

Seligman, M. (2006). Learned optimism: How to change your mind and your life. New York: Vintage books.

Semaraputri, S. A. K. T., \& Rustika, I. M. (2018). Peran Problem Focused Coping Dan Konsep Diri Terhadap Penyesuaian Diri Pada Remaja Akhir Yang Menjadi Pengurus Organisasi Kemahasiswaan Di Fakultas Kedokteran Universitas Udayana. Jurnal Psikologi Udayana, 5(1), 35-47.

Sugiyono. (2011). Metode Penelitian Kuantitatif Kualitatif dan R\&D. Alfabeta: Bandung. 